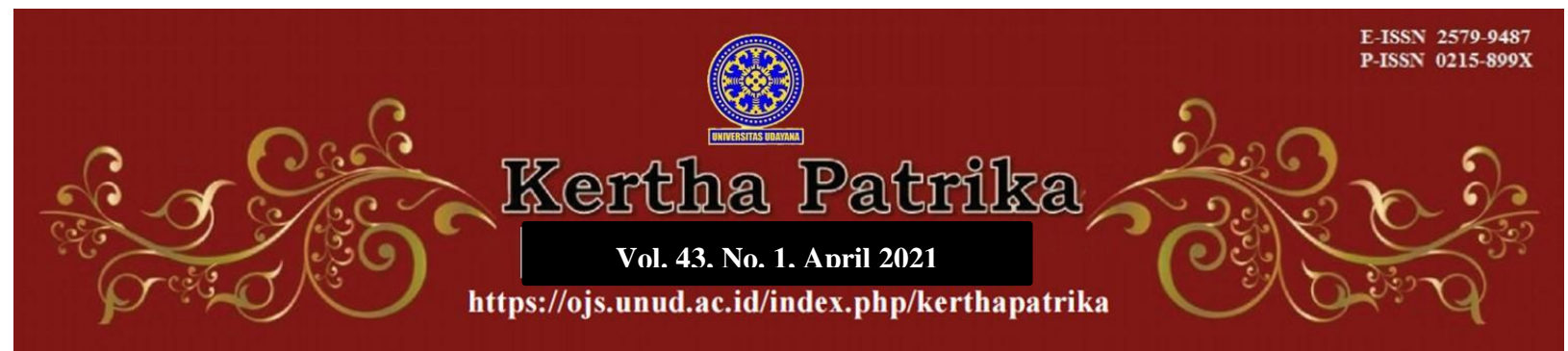

\title{
Orientasi Kesejahteraan dalam Pengaturan Subak Sebagai Warisan Budaya Dunia
}

\section{Gusti Agung Mas Rwa Jayantiari¹, AA Gede Oka Parwata² , I Gusti Ngurah Dharma Laksana $^{3}$}

${ }^{1}$ Fakultas Hukum Universitas Udayana, E-mail: mas_jayantiari@unud.ac.id

2 Fakultas Hukum Universitas Udayana, E mail: oka_parwata@unud.ac.id

${ }^{3}$ Fakultas Hukum Universitas Udayana, E-mail: dharma_laksana@unud.ac.id

\begin{tabular}{l}
\hline Info Artikel \\
Masuk : 6 Oktober 2020 \\
Diterima : 20 April 2021 \\
Terbit : 28 April 2021 \\
Keywords : \\
Welfare Orientation; Subak; \\
Regulation; Bali \\
\\
\\
Corresponding Author: \\
I Gusti Agung Mas Rwa \\
Jayantiari, E-mail: \\
mas_jayantiari@unud.ac.id \\
DOI : \\
10.24843/KP.2021.v43.i01.p06 \\
Kata kunci: \\
Prientasi Kesejahteraan; Subak; \\
\end{tabular}

\begin{abstract}
Subak, as a functional unit of customary community law in Bali, has been passed down from generation to generation to support the prosperity of its members by upholding the live philosophy of Tri Hita Karana. However, the recognition of subak as the world cultural heritage by UNESCO raises problems concerning the existence of subak due to the regulation by state law through various policies according to the status of subak. The objective of this study is to analyze the regulation of Subak related to a welfareoriented state law provisions, which is inline withthe ideal expectations of the members of the subak in particular, and to realize the State's goal to advance the general welfare. $=$ This is considering the dominant economic and tourism pace leading to the commercialization of the potential of subak. It is a normative legal research that applies statutory and conceptual approaches. This study found that the welfare orientation in the subak arrangement had not been optimally formulated because it was still determined in various rules related to subak. Moreover, there were inconsistencies in the provisions and the formation of a subak management board that was more focused on tourism-economic benefits.
\end{abstract}


dengan pendekatan perundang-undangan dan pendekatan konsep. Penelitian ini menemukan bahwa orientasi kesejahteraan dalam pengaturan subak belum secara optimal dirumuskan karena masih ditentukan dalam berbagai aturan terkait subak. Apalagi terdapat inkonsistensi ketentuan dan dibentuknya Dewan Pengelola Warisan Budaya Bali, diantaranya adalah Badan Pengelola Daya Tarik Wisata sebagai pengelola subak yang lebih berpusat pada keuntungan ekonomi.

\section{Pendahuluan}

Dalam tatanan kemasyarakatan di Bali, subak telah ada secara turun-temurun sebagai pilar penyangga kebudayaan karena melekat pola budaya ekologi, pertanian dan sosio religiositas berlandaskan Tri Hita Karana. Persepsi kuat masyarakat petani Bali dalam keanggotaan subak adalah harapan mewujudkan kesejahteraan anggotanya dengan pola organisasi yang teratur dalam pengelolaan lahan dan irigasi seimbang berdasarkan nilai ketuhanan, kemanusiaan dan lingkungannya. Jika dilihat fakta strategis atas fungsinya, maka tepat apa yang ditentukan Putusan Mahkamah Konstitusi Nomor 31/PUU-V/2007. Dalam uraian risalah sidang perkara yang acara pengucapan putusan (V) dilakukan pada 18 Juni 2008 yang menentukan unsur-unsur kesatuan masyarakat hukum adat, ditentukan bahwa subak adalah aspek yang fungsional. Hal ini sesuai dengan fungsi subak sebagai organisasi menyelenggarakan kepentingan bersama anggotanya sebagai sumber pendapatan sehingga sudah semestinya mendapat perlindungan yang maksimal. ${ }^{1}$ Pusat Data dan Statistik Pendidikan dan Kebudayaan Kementerian Pendidikan dan Kebudayaan tahun 2019 juga memuat analisis yang menyatakan pentingnya kesejahteraan petani subak karena pola pertanian bermuatan kearifan lokal pada subak menjadi kekuatan pokok ketahanan hayati dan pangan. ${ }^{2}$

Kesatuan masyarakat hukum adat fungsional yang melekat pada subak memberi arti penting untuk menjaga kelestarian alam. Kesatuan wilayah persawahan dalam subak dikelola dengan penataan yang khas telah menjadi budaya pertanian yang berkelanjutan dan hal ini ternyata selaras dengan prinsip-prinsip konservasi, lingkungan berkelanjutan dan sumber daya alam seperti yang dimaksud oleh United Nations Educational Scientific and Cultural Organization (UNESCO). Sehingga Subak pada 2012 ditetapkan sebagai warisan budaya dunia oleh UNESCO melalui Desicion Code:36 COM 8B. 29.3 Penetapan subak sebagai warisan budaya dunia dengan filosofi yang berintikan harmonisasi alam tertuang dalam putusan badan dunia yang menangani bidang kebudayaan tersebut. Hal ini berarti menjadi ekspresi pengakuan UNESCO atas

1 Aryawan, I. P. S., Windia, W., \& Wijayanti, P. U. (2013). Peranan Subak dalam Aktivitas Pertanian Padi Sawah (Kasus di Subak Dalem, Kecamatan Kerambitan, Kabupaten Tabanan). Jurnal Agribisnis dan Agrowisata (Journal of Agribusiness and Agritourism) 2(1), h. 2

2 Mas'ad. (2019). Analisis Kelestarian Subak Pasca Ditetapkan Menjadi Warisan Budaya Dunia Oleh UNESCO. Jakarta: Kementerian Pendidikan dan Kebudayaan Sekretariat Jendral Pusat Data dan Statistik Pendidikan dan Kebudayaan, h.2.

${ }^{3}$ UNESCO. Cultural Properties - Cultural Landscape of Bali Province: the Subak System as a Manifestation of the Tri Hita Karana Philosophy (Indonesia). Available from https://whc.unesco.org/en/decisions/4797/. (Diakses 1 Juli 2020). 
keberadaan subak sebagai lembaga pengairan tradisional bercorak khas kearifan lokal masyarakat petani di Bali dalam mengelola alam lingkungan sawah secara lestari dan mengatur irigasi pertanian yang memberi manfaat dan kesejahteraan bagi masyarakat petani subak pada khususnya.

Windia dan Wiguna menilai bahwa karena nilai-nilai budaya yang luar biasa (outstanding values) yang tetap hidup sampai sekarang yang tercermin dari nilai keaslian (authenticity) dan budaya subak dapat diterima sebagai nilai universal semua lapisan masyarakat Bali. Predikat warisan budaya dunia diharapkan dapat memberikan manfaat kesejahteraan khususnya bagi masyarakat petani anggota subak sebagai pelaku utama serta masyarakat lokal di sekitar kawasan, dan memberikan kontribusi dengan modal kesederhanaan dan keunikan adat budayanya. ${ }^{4}$ Lebih lanjut Windia berpendapat bahwa pengakuan subak yang didasarkan filosofi Tri Hita Karana, subak dengan wujud bentang alam adalah lanskap yang berisikan muatan aktivitas budaya ${ }^{5}$.

Pengaturan menurut ketentuan hukum negara dengan produk hukumnya dalam pengelolaan subak menjadi kunci atas harapan tetap eksisnya organisasi tradisional berkarakteristik khas dengan fungsinya yang strategis tersebut. Perlindungan atas subak dimaksimalkan karena hal ini tidak terlepas dari peran negara dalam memajukan kesejahteraan umum sebagai suatu tanggung jawab pada rakyat. Namun tuntutan global pada prioritas pertumbuhan ekonomi harus diakui berdampak pada subak dengan semua potensinya menjadi salah satu modal kepariwisataan, penopang sumber pendapatan Bali di sektor pariwisata. ${ }^{6}$ Problem pengaturan yang harus tetap mengakomodir aspek modal tersebut menjadi hal penting untuk memastikan eksistensi subak agar tetap sesuai harapan keadilan dan kesejahteraan. Dengan demikian orientasi kesejahteraan dalam pengaturan subak sebagai warisan budaya menjadi urgen untuk dikaji lebih lanjut sebagai komitmen mewujudkan kesejahteraan dan sesuai dengan amanat tujuan negara. Hal utama yaitu perlindungan subak, bukan lebih berprioritas pada pengembangan investasi yang berpihak bagi dunia usaha yang kemudian cenderung mengeksploitasi subak.

Bila dilihat dari optik kepariwisataan, lanskap subak dengan bentang sawah dan pemandangannya adalah komoditi yang potensial. Berbeda halnya apabila dilihat dari sudut masyarakat, sawah menjadi aset utama sumber penghidupan dari aspek bernilai ekonomis, agraris, sosial, kultural, dan religius. Sayangnya pergeseran cara pandang terhadap aspek ekonomi dengan memperhitungkan pada nilai rupiah lahan, bukan bagaimana hasil yang didapat secara berkelanjutan dengan mengolah dan memperoleh nilai manfaat dari sawah. ${ }^{7}$ Fakta pergeseran tersebut dinilai oleh Supratikno Rahardjo bahwa pengaturan warisan budaya semestinya mengacu pada upaya terwujudnya

\footnotetext{
${ }^{4}$ Windia, I. W., \& Wiguna, W. A. A. (2013). Subak Warisan Budaya Dunia. Udayana University Press, h. 205.

5 Windia, W. (2013). Penguatan Budaya Subak Melalui Pemberdayaan Petani. Jurnal Kajian Bali (Journal of Bali Studies), 3(2), h.137.

6 Kohdrata, N., \& Sutrisna, P. E. (2011). Konservasi Subak Anggabaya: Suatu Model Konservasi Lanskap Bali. Jurnal Lanskap Indonesia, 3(1), h.42.

7 Ibid.
} 
kesejahteraan. Apabila dipilah makna yang berkait pada aspek pengelolaan yaitu pada aspek perlindungan, pengembangan, dan pemanfaatan. ${ }^{8}$

Berdasarkan problematika yang telah diuraikan di atas, maka penting untuk mengkaji bagaimana pengaturan lanskap subak sebagai warisan budaya dunia, baik menurut ketentuan UNESCO, maupun dalam perundang-undangan Indonesia dan apakah pengaturan tentang subak telah mencerminkan orientasi kesejahteraan dengan adanya penetapan subak sebagai warisan budaya dunia.

\section{Metode Penelitian}

Di dalam penelitian ini digunakan metode yuridis normatif, yaitu mengkaji norma hukum. ${ }^{9}$ Permasalahan dikaji lebih mendalam dengan pendekatan undang-undang ,yang tujuannya adalah untuk mengetahui konsistensi atau kesesuaian antara peraturan perundang-undangan tentang subak. Selain itu digunakan pula pendekatan konsep yaitu menganalisis konsep dasar, pendapat dan pandangan ahli yang telah menjadi doktrin sesuai perkembangan keilmuan hukum. Pendekatan konsep dilakukan dalam rangka memperoleh pemahaman dan relevansi dengan problematika yang diteliti untuk melihat subak diatur menurut ketentuan hukum negara dan orientasi kesejahteraan dalam pengaturan tersebut. Bahan-bahan hukum diteliti dan dikaitkan dengan pokok permasahan utamanya pada peraturan perundang-undangan yang terkait dalam pengaturan subak sebagai warisan budaya dunia.

\section{Hasil dan Pembahasan}

\subsection{Pengaturan Subak Sebagai Warisan Budaya Dunia}

Penetapan UNESCO yang menempatkan subak sebagai warisan budaya dunia secara substantif dituangkan dalam Dokumen Rencana Pengelolaan pada intinya termasuk kategori lanskap budaya, bentuknya memadukan unsur kesejahteraan manusia dan kelestarian alam. Untuk melihat bagaimana selanjutnya negara mengakui eksistensi subak dapat diurai dengan fakta keberadaannya sebagai kesatuan masyarakat hukum adat, melekat hak-hak tradisionalnya sehingga dalam konstitusi dilihat sesuai apa yang dinyatakan Pasal 18B ayat (2) Undang-Undang Dasar Negara Kesatuan Republik Indonesia Tahun 1945 (UUD NRI 1945), yang menentukan : Negara mengakui dan menghormati kesatuan masyarakat hukum adat beserta hak-hak tradisionalnya sepanjang masih hidup dan sesuai dengan perkembangan masyarakat dan prinsip Negara Kesatuan Republik Indonesia yang diatur dalam undang-undang. Asas hukum yang tercantum dalam ketentuan tersebut sesuai dengan nilai dasar yang terkandung dalam Pembukaan UUD NRI 1945, yaitu penghargaan terhadap hak dasar kemanusiaan dan kebudayaan.

Jaminan dalam konstitusi memberi penegasan bahwa negara mengakui, menghormati serta berkewajiban memberikan perlindungan, pemajuan, penegakan dan pemenuhan

\footnotetext{
8 Rahardjo, S. (2013). Beberapa Permasalahan Pelestarian Kawasan Cagar Budaya dan Strategi Solusinya. Jurnal Konservasi Cagar Budaya Borobudur, 7(2), h. 6.

9. Mukti Fajar, N. D., \& Achmad, Y. (2010). Dualisme Penelitian Hukum: Normatif \& Empiris. Pustaka Pelajar, h. 34
} 
terhadap hak-hak tradisional masyarakat adat, yang merupakan hak konstitusional seluruh rakyat, termasuk hak lembaga subak sebagai persekutuan hukum adat dalam kepemilikan warisan budaya dunia di Bali. Lembaga subak sebagai organisasi sosial yang berprioritas pada peningkatan kesejahteraan anggotanya secara khusus dan masyarakat sekitarnya secara umum. Kesehariannya, anggota komunitas ini mengatur pembagian air persawahan secara adil dan terbagi secara merata. Pola irigasi yang secara turun-temurun adalah salah satu kearifan lokal tradisi berkelanjutan sehingga pengakuan pada keberadaan subak beserta hak tradisionalnya tersebut adalah suatu wujud perlindungan nilai budaya bangsa. ${ }^{10}$

Pengaturan hak kebudayaan juga diatur dalam Pasal 28I ayat (3) UUD NRI 1945, menentukan: Identitas budaya dan hak-hak masyarakat tradisional dihormati selaras dengan perkembangan zaman dan peradaban. Esensi pasal ini memberi arah dalam pengelolaan warisan budaya, termasuk dalam penentuan sistem kelembagaannya, harus memperhatikan nilai historis kultural masyarakat hukum adat yang merupakan hak yang dijamin oleh konstitusi, sehingga pelanggaran terhadap hak-hak tersebut merupakan pelanggaran terhadap hak-hak konstitusional masyarakat adat.

Masih dilihat dari aspek kebudayaan, pengaturan lebih lanjut tentang kebudayaan juga dapat dilihat dalam Pasal 32 ayat (1) UUD NRI 1945), yang menentukan bahwa Negara memajukan kebudayaan nasional Indonesia di tengah peradaban dunia dengan menjamin kebebasan masyarakat dalam memelihara dan mengembangkan nilai-nilai budayanya. Ketentuan konstitusional ini menunjukkan negara berkewajiban mengambil langkah-langkah dan upaya dalam usaha memajukan, dan memberikan jaminan dan perlindungan terhadap kebudayaan nasional serta dihormatinya hak-hak tradisional pengelolaan warisan budaya.

Tingkatan pengaturan setelah dalam UUD NRI 1945, ditentukan melalui perundangundangan yang ada hubungannya dengan pengaturan warisan budaya, antara lain:

(I) Undang-Undang Nomor 5 Tahun 2017 tentang Pemajuan Kebudayaan (UU Pemajuan Kebudayaan). Dalam Pasal 4 undang-undang ini ditentukan bahwa tujuan pemajuan kebudayaan bermuara pada meningkatnya kesejahteraan rakyat. Konteks budaya dalam undang-undang ini ditujukan serangkaian pengembangan nilai luhur bangsa sehingga budaya yang beragam adalah unsur jati diri yang menjadi penguat persatuan dan kesatuan. Hal lain dimaksudkan pula oleh ketentuan pasal ini adalah peningkatan kecerdasan dan citra diri bangsa untuk terwujudnya masyarakat madani. Budaya bangsa yang diwarisi ditentukan undangundang ini adalah sebagai haluan bagi pembangunan nasional. Penjabaran pasal tersebut secara ideal menghendaki bahwa lanskap subak hendaknya dikelola dengan maksud peningkatan kesejahteraan masyarakat petani subak. Hal yang utama juga tertuju pada pengembangan budaya bangsa dan nilai-nilai luhur yang dikandungnya.

(II) Undang-Undang Nomor 23 Tahun 2014 tentang Pemerintah Daerah. Dalam hal kewenangan berkait bidang budaya ditentukan melalui Pasal 9 (1), mengatur

10 Artatik, I. K., Kumara, G. J., \& Wibawa, I. P. S. (2019). Subak Sebagai Kesatuan Masyarakat Hukum Adat (KMHA): Perspektif Kemajemukan Hukum. Vidya Wertta: Media Komunikasi Universitas Hindu Indonesia, 2(2), 221-233. 
tentang pembagian urusan pemerintahan. Urusan pemerintahan terbagi dalam 3 poin penting yakni absolut, konkuren umum. Khusus untuk konkuren inilah dalam ayat (3) dari pasal tersebut menjadi dasar pelaksanaan otonomi daerah yang menyangkut pula urusan kebudayaan.

(III) Undang-Undang Nomor 11 Tahun 2010 tentang Cagar Budaya (UUCB). Pasal 13 undang-undang ini menentukan bahwa hanya negara yang dapat memiliki dan/atau menguasai kawasan cagar budaya, kecuali secara turun-temurun dimiliki oleh masyarakat hukum adat. Prinsip pengembangan cagar budaya berdasar Pasal 78 (1) UUCB menentukan perhatiannya pada unsur nilai yang melekat pada cagar budaya tersebut dengan mempertimbangkan kemanfaatan, keamanan, keterawatan, keasliannya.

Inventarisasi pengaturan sebagaimana yang ditemukan di atas memang secara langsung lebih tertuju kepada aspek budaya yang tidak lepas dari keberadaan komunitas adat. Dalam skala nasional ini, pengaturan secara langsung yang mempertegas status subak sebagai warisan budaya dunia tidak ditemukan. Pengaturannya, hanya dapat dilihat secara tidak langsung saja melalui ketentuan undang-undang sebagaimana dibahas di atas, yang pada beberapa pasal secara substantif banyak memberi pengaruh bagi eksistensi subak. Pengelolaan langsung kebudayaan ada pada pemerintah pusat menjadi disharmoni terutama dilihat dari aspek nilai-nilai filosofis Tri Hita Karana yang sarat dengan corak dan identifikasi khas daerah. Makna inti Tri Hita Karana sendiri memuat nilai dasar kearifan lokal (local wisdom) menjada tiga dimensi penting hubungan keseimbangan alam yang didasari nilai harmonisasi ketuhanan, antar sesama, dan menjaga lingkungan. Demikian pula apabila konteksnya memberi perlindungan pada cagar budaya dengan dinyatakan dominannya dikuasai negara, sehingga sifatnya terpusat padahal konsep subak berintikan kearifan lokal, corak khas daerah yang sangat khas menjadi tidak terakomodir.

Lebih lanjut bila dilihat dengan kewenangan melalui peraturan daerah, Pemerintah Provinsi Bali (Pemda Bali) telah mengeluarkan berbagai produk hukum daerah yang berhubungan dengan warisan budaya sebagai bentuk perlindungan, serta memberikan penguatan terhadap fungsi-fungsi kebudayaan. Masing-masing pengaturan ini akan diuraikan sebagai berikut:

(I) Peraturan Daerah Provinsi Bali Nomor 16 Tahun 2009 tentang Rencana Tata Ruang Wilayah Provinsi Bali (selanjutnya disebut Perda RTRW), terutama sesuai Pasal 1 angka 6 dengan spirit Tri Hita Karana dasar falsafah agama Hindu Bali sekaligus landasan bagi bertahannya subak sebagai warisan budaya. Hal ini menjadi kuat karena harmonisasi yang diciptakan oleh seimbangnya hubungan antara manusia dengan Tuhan, manusia dengan sesamanya, dan manusia dengan alam lingkungannya sehingga menjadi sumber utama kehidupan manusia, damai, sejahtera dan bahagia.

(II) Peraturan Daerah Provinsi Bali Nomor 9 Tahun 2012 tentang Subak. (Selanjutnya disebut Perda Subak). Subak dalam perda tersebut dinyatakan sebagai komponen budaya Bali, irigasi sawahnya diatur sedemikian rupa, penggunaan air yang adil dan pengelolaan sawah itu sendiri dengan karakteristik sistem parahyangan, pawongan, dan palemahan. Tiga wujud falsafah Tri Hita Karana ini dijabarkan dalam 
ketentuan umum perda tersebut, parahyangan menujuk hubungan ketuhanan, pawongan pada aspek sesama anggota,dan palemahan menunjuk pada aspek wilayah subak tersebut.

(III) Peraturan Daerah Provinsi Bali Nomor 4 Tahun 2014 tentang Pelestarian Warisan Budaya Bali (selanjutnya disebut Perda PWB). Hal utama dalam Pasal 1 Ayat 5 yang mengatur bahwa pelestarian warisan budaya Bali merupakan suatu kegiatan perlindungan, pemeliharaan, pengembangan dan pemanfaatan warisan budaya Bali. Pasal 3 huruf d menentukan: Pelestarian mencakup "pemanfaatan". Penjabaran asas tersebut dapat dilihat dalam Pasal 17, yang menentukan aspek kepentingan yang dapat diwujudkan oleh pemegang hak penguasaan. Dalam hal pemanfaatannya, pemegang hak memperhatikan terselenggaranya kegiatan bidang agama, bidang sosial budaya menyangkut pendidikan, kepariwisataan, pengetahuan, dan teknologi. Terhadap bagaimana perlindungan warisan budaya dilakukan, ketentuan Pasal 13 (2) menyatakan bahwa, perhatian terhadap hak-hak komunitas adat yaitu hak-hak kultural sejarah, dan hukumnya dijadikan pedoman oleh pemerintah daerah.

Apabila ditelusuri lebih lanjut dalam Peraturan Gubernur Bali Nomor 32 Tahun 2010 tentang Dewan Pengelola Warisan Budaya Bali, suatu kondisi kontradiktif ditemukan dengan otonomi pengelolaan subak oleh komunitasnya sendiri sesuai dengan awig-awig (aturan berdasar hukum adat yang dirumuskan krama/anggota subak). Pembentukan Dewan Pengelola Warisan Budaya Bali yang kemudian ada berbentuk Badan Pengelola Daya Tarik Wisata menunjukkan bagaimana subak dilihat sebagai sesuatu yang dikelola untuk pariwisata sebagai fokusnya sehingga telah bergeser dari esensi menjadikan subak sebagai warisan budaya dunia yang dimaksudkan untuk menjaga kelestarian subak. Awig-awig subak adalah pedoman subak untuk kesejahteraan dan dikelola sesuai penetapan warisan budaya dunia yang terlindungi. Pengakuan de jure negara terhadap keberadaan subak dengan bentuk produk dan tindakan hukum seperti yang telah diuraikan pada satu sisi menjadi penting untuk pengakuan eksistensi subak, namun penguatannya justru adalah dengan terserapnya nilai-nilai kearifan lokal yang telah tertuang pada awig-awig subak.

Hal menarik dari inventarisasi pengaturan di atas pada akhirnya tidak dapat dilepaskan dari fungsi dari pengaturan oleh negara dalam pemenuhan kebutuhan masyarakat menjadi bagian dari penegasan hukum harus senantiasa mengikuti perkembangan masyarakat agar ia mampu menjadi sarana yang efektif. Subak dalam pengaturan oleh negara sesuai intisari dikeluarkannya produk hukum oleh negara adalah dalam rangkaian menjawab kebutuhan masyarakat sehingga hukum harus secara responsif mengakomodir kebutuhan hukum dalam masyarakat. ${ }^{11}$

Persoalan adanya kontradiksi dalam aspek-aspek pengakuan terhadap warisan budaya, bila dilihat perspektif eksternal dan internal perkembangan dan kepentingan pembuatan peraturan, yaitu didasari pada aspek filosofis, sosiologis, serta politisnya, berakibat bahwa dibentuknya peraturan perundang-undangan tidak dapat dilepaskan

11 Redi, Ahmad. (2018). Hukum Pembentukan Peraturan Perundang-Undangan. Sinar Grafika, h. 103. 
oleh adanya intervensi politik hukum pembentuknya. Tafsir atas dinamika dan kondisi kepentingan ekonomi dan investasi yang sedang berlangsung. ${ }^{12}$

\subsection{Orientasi Kesejahteraan dalam Pengaturan Subak Sebagai Warisan Budaya Dunia}

Kewenangan negara yang diberikan kepada pemerintah untuk mengatur dan mengelolanya bagi kesejahteraan rakyat dapat dipahami bahwa artikulasi kewenangan ini kemudian melahirkan berbagai kebijakan dan perangkat ketentuan hukum yang ditetapkan negara dalam rangka mewujudkan keadilan, kesejahteraan, dan kemanfaatannya bagi masyarakat luas. ${ }^{13}$ Apabila dikaitkan dengan UU Pemda termuat dalam lampiran matrik I angka 7 bahwa aspek pembagian urusan bidang kebudayaan menyangkut pengelolaan warisan budaya dunia oleh pemerintah pusat tentu orientasi kesejahteraan akan bersifat sentralistrik. Wujudnya tentu kebijakan yang dituangkan lebih mewakili kepentingan pemerintah padahal menurut rumusan teori negara kesejahteraan/ welfare state, adalah dalam pencapaian kesejahteraan rakyat.Intinya seperti yang diuraikan oleh F. Isjwara, dalam dimensi waktu yang lalu hingga mendatang dalam welfare state warga negaralah yang menjadi pusat kesejahteraan. ${ }^{14}$

Tujuan yang kian penting yaitu pada bahwa kepentingan umum dilaksanakan secara luas yang lazimnya berkaitan dengan fungsi kesejahteraan umum. Hal ini menjadi perluasan atas fungsi keamanan dan ketertiban negara yang secara aktif memberi peran menjamin terjaganya kepentingan umum. Negara disebut juga sebagai suatu lembaga sosial yang hadir karena dikehendaki untuk pemenuhan kebutuhan yang beragam. Tetapi peran yang ada pada negara kesejahteraan bukan bagi kebutuhan segolongan orang namun rakyat negara menjadi prioritas utama. ${ }^{15}$

Orientasi kesejahteraan memang menjadi salah satu acuan apabila dilihat begitu besarnya potensi yang dimiliki negara untuk dapat menuangkannya dalam berbagai produk hukum. Bekerjanya hukum berkaitan dengan eksistensi kesatuan masyarakat hukum adat dan juga hak-haknya dihadapkan pada prioritas pembangunan yang terpusat pada keuntungan ekonomi yang diwujudkan dengan keberpihakan pada pelaku ekonomi, menghasilkan resultante masyarakat hukum adat yang belum sejahtera. Kondisi yang demikian sangat kontradiktif dengan salah satu tujuan berdirinya NKRI yang antara lain untuk memajukan kesejahteraan umum seperti ditegaskan dalam Alinea IV Pembukaan UUD NRI 1945 ,Pasal 33 ayat (3) dan Pasal 34 ayat (2). Ketentuan Pasal 33 ayat (3) UUD NRI 1945 menentukan bumi air dan kekayaan alam yang terkandung di dalamnya dikuasai oleh negara dan digunakan untuk sebesar-besar kemakmuran rakyat. Adapun Pasal 34 ayat (2) UUDNRI 1945 menentukan Negara mengembangkan sistem jaminan sosial bagi seluruh rakyat dan memberdayakan masyarakat sesuai dengan martabat kemanusiaan. ${ }^{16}$

12 Susetio, W. (2013). Disharmoni peraturan perundang-undangan di Bidang Agraria. Lex Jurnalica, 10(3), h.143.

13 Puri, W. H. (2017). Pluralisme Hukum sebagai Strategi Pembangunan Hukum Progresif di Bidang Agraria di Indonesia. BHUMI: Jurnal Agraria dan Pertanahan, 3(1), 67-81.

14 Nugroho, B. D. (2015). Hukum Adat: Hak Menguasai Negara Atas Sumber Daya Alam Kehutanan dan Perlindungan Terhadap Masyarakat Hukum Adat. Refika Aditama, h. 2

15 Ibid.

16 Sukirno. (2018). Politik Hukum Pengakuan Hak Ulayat. Prenadamedia Group, h.101. 
Yogi Setya Permana dalam penelitiannya menguraikan dan merefleksikan bahwa produk hukum yang berorientasi kesejahteraan akan menjadi penyangga dalam menghadapi perkembangan dan krisis multi dimensi yang memberi pengaruh langsung pada ketahanan organisasi subak. Kondisi yang memprihatinkan ini ditunjukkan dengan jumlah komunitas subak di Bali yang dari tahun ke tahun menunjukkan penurunan Berkurangnya jumlah komunitas subak secara signifikan tersebut seiring dengan semakin menyusutnya lahan pertanian karena alih fungsi lahan, kurangnya pasokan air hingga tingginya pajak bumi dan bangunan. ${ }^{17}$

Perlindungan yang mengarah kepada penguatan terhadap lembaga subak itu sendiri didasari konsep negara hukum yang mensejahterakan rakyatnya, dimana dengan ditetapkannya subak sebagai warisan budaya dunia, memberikan manfaat berupa kesejahteraan bagi masyarakat subak yang meliputi keadilan, kedamaian, ketentraman hidup dan jaminan bagi warganya. Problematika yang ada justru pada aksesibilitas (kemudahan-kemudahan) masyarakat terhadap warisan budaya subak akan menjadi semakin berkurang dengan bergesernya prioritas kelembagaan yang mengelola subak lebih berfokus kepada komodifikasi kepentingan ekonomi. Orientasi atas kesejahteraan mudah bergeser dengan perkembangan pesat yang membutuhkan prioritas perhatian dan pengelolaan warisan budaya. Hal ini patut diwaspadai, karena menjadikan subak sebagai warisan budaya dunia menempatkan pula sebagai sumber potensi kepariwisataan. Daya tarik ini justru menjadikan subak terbawa ke situasi global, pemanfaatan yang bisa menyebabkan dampak negatifnya sangat besar. Apabila pengaturan menentukan kewenangan sentralistik bahkan Dewan Pengelola Warisan Budaya Bali kemudian ada yang berbentuk menjadi Badan Pengelola Daya Tarik Wisata tentu orientasi untuk kesejahteraan tidak maksimal dapat diwujudkan. Hal yang lebih terlihat justru eksploitasi subak untuk kepentingan ekonomis, bukan dalam kerangka yang menjadikannya tumpuan kehidupan anggota krama subak dan terjaganya unsur kearifan lokal yang tertuju pada hubungan harmonis ketuhanan, sesama dan lingkungan alam yang lestari berkelanjutan.

\section{Kesimpulan}

Pengaturan subak ditemukan pada peraturan perundang-undangan yang terkait hak kesatuan masyarakat hukum adat (fungsional) dan aspek kebudayaan. Dalam aspek pengelolaan oleh adanya kewenangan negara maka tidak dapat dilepaskan dari pengaturan dalam produk hukum berkala nasonal dan daerah. Dalam peraturan yang memberikan kewenangan atas pengelolaan warisan budaya nasional dan dunia ini dilaksanakan oleh pemerintah pusat yang ditentukan UU Pemda tidak sesuai dengan UU Cagar Budaya yang menentukan kewenangan berada pada pemerintah daerah. Sementara untuk pengaturan oleh pemerintah daerah dengan membentuk Dewan Pengelola Warisan Budaya dan diwujudkan di antaranya berbentuk Badan Pengelola Daya Tarik Wisata menjadi suatu isyarat bahwa orientasi pada kesejahteraan menjadi belum optimal dalam pengelolaan subak. Situasi yang menunjukkan kontradiksi adanya pengabaian hak masyarakat hukum adat (subak) termasuk hak otonomi dalam

\footnotetext{
17 Permana, Y. S. (2018). Mampukah Subak Bertahan? Studi Kasus Ketahanan Sosial Komunitas Subak Pulagan, Gianyar, Bali. Masyarakat Indonesia, 42(2), 219-232.
} 
pengelolaan subak sebagai warisan budaya, sehingga dapat berpengaruh pada aspek kemanfaatan dan kesejahteraan bagi masyarakat subak itu.

Orientasi kesejahteraan belum dituangkan sesuai desain negara kesejahteraan (welfare state), yaitu negara yang pemerintahnya bertanggung jawab memberi jaminan kesejahteraan sesuai standar yang baik bagi warga negaranya. Perspektif yang dilihat seharusnya pada strategis peran subak sebagai penyangga pembangunan lingkungan berkelanjutan yang secara turun temurun dan menjadi harapan kesejahteraan krama (anggota) Subak. Konsep negara hukum yang mensejahterakan rakyatnya belum sepenuhnya dapat terwujud karena dalam pengaturan subak hal yang mendasar pada pada proses legislasi Indonesia, terjadi dikarenakan perhatian akan kesejahteraan belum menjadi prioritas. Pengabaian terhadap ekspektasi (harapan) komunitas (kelompok sosial) yang dalam konteks ini adalah pengabaian terhadap harapan komunitas subak karena prioritas menjadi beralih pada perkembangan dunia usaha dan keuntungan ekonomi dengan adanya penetapan warisan budaya dunia.

\section{Daftar Pustaka / Daftar Referensi}

\section{Buku}

Mas'ad. (2019). Analisis Kelestarian Subak Pasca Ditetapkan Menjadi Warisan Budaya Dunia Oleh UNESCO. Jakarta: Kementerian Pendidikan dan Kebudayaan Sekretariat Jendral Pusat Data dan Statistik Pendidikan dan Kebudayaan.

Mukti Fajar, N. D., \& Achmad, Y. (2010). Dualisme Penelitian Hukum: Normatif \& Empiris. Pustaka Pelajar

Nugroho, B. D. (2015). Hukum Adat: Hak Menguasai Negara Atas Sumber Daya Alam Kehutanan dan Perlindungan Terhadap Masyarakat Hukum Adat. Refika Aditama.

Redi, Ahmad. (2018). Hukum Pembentukan Peraturan Perundang-Undangan. Sinar Grafika. Sukirno. (2018). Politik Hukum Pengakuan Hak Ulayat. Prenadamedia Group.

Windia, I. W., \& Wiguna, W. A. A. (2013). Subak Warisan Budaya Dunia. Udayana University Press

\section{Jurnal}

Artatik, I. K., Kumara, G. J., \& Wibawa, I. P. S. (2019). Subak Sebagai Kesatuan Masyarakat Hukum Adat (KMHA): Perspektif Kemajemukan Hukum. Vidya Wertta: Media Komunikasi Universitas Hindu Indonesia, 2(2).

Aryawan, I. P. S., Windia, W., \& Wijayanti, P. U. (2013). Peranan Subak dalam Aktivitas Pertanian Padi Sawah (Kasus di Subak Dalem, Kecamatan Kerambitan, Kabupaten Tabanan). Jurnal Agribisnis dan Agrowisata (Journal of Agribusiness and Agritourism) 2(1) .

Kohdrata, N., \& Sutrisna, P. E. (2011). Konservasi Subak Anggabaya: Suatu Model Konservasi Lanskap Bali. Jurnal Lanskap Indonesia, 3(1).

Permana, Y. S. (2018). Mampukah Subak Bertahan? Studi Kasus Ketahanan Sosial Komunitas Subak Pulagan, Gianyar, Bali. Masyarakat Indonesia, 42(2) .

Puri, W. H. (2017). Pluralisme Hukum sebagai Strategi Pembangunan Hukum Progresif di Bidang Agraria di Indonesia. BHUMI: Jurnal Agraria dan Pertanahan, 3(1).

Rahardjo, S. (2013). Beberapa Permasalahan Pelestarian Kawasan Cagar Budaya dan Strategi Solusinya. Jurnal Konservasi Cagar Budaya Borobudur, 7(2).

Susetio, W. (2013). Disharmoni peraturan perundang-undangan di Bidang Agraria. Lex Jurnalica, 10(3). 
Windia, W. (2013). Penguatan Budaya Subak Melalui Pemberdayaan Petani. Jurnal Kajian Bali (Journal of Bali Studies), 3(2).

Online/World Wide Web:

UNESCO. Cultural Properties - Cultural Landscape of Bali Province: the Subak System as a Manifestation of the Tri Hita Karana Philosophy (Indonesia). Available from https://whc.unesco.org/en/decisions/4797/. (Diakses 1 Juli 2020)

\section{Peraturan Perundang-Undangan}

Undang-Undang Dasar Negara Republik Indonesia Tahun 1945

Undang-Undang Republik Indonesia Nomor 11 Tahun 2010 Tentang Cagar Budaya, Lembaran Negara Republik Indonesia Tahun 2010 Nomor 130, Tambahan Lembaran Negara Negara Republik Indonesia Nomor 5168.

Undang-Undang Republik Indonesia Nomor 23 Tahun 2014 Tentang Pemerintahan Daerah, Lembaran Negara Republik Indonesia Tahun 2014 Nomor 244, Tambahan Lembaran Negara Republik Indonesia Nomor 5587

Undang-Undang Undang-Undang Nomor 5 Tahun 2017 Tentang Pemajuan Kebudayaan, Lembaran Negara Republik Indonesia Tahun 2017 Nomor 104, Tambahan Lembaran Negara Republik Indonesia Nomor 6055.

Peraturan Daerah Provinsi Bali Nomor 9 Tahun 2012 Tentang Subak, Lembaran Daerah Provinsi Bali Tahun 2012 Nomor 9.

Peraturan Daerah Provinsi Bali Nomor 4 Tahun 2014 tentang Pelestarian Warisan Budaya Bali (selanjutnya disingkat Perda PWB), Lembaran Daerah Provinsi Bali: (4/2014).

Peraturan Gubernur Bali Nomor 32 Tahun 2010, Tentang Dewan Pengelola Warisan Budaya Bali, Berita Daerah Provinsi Bali Tahun 2010 Nomor 32.

Keputusan Gubernur Bali Nomor 11/03-H/HK/2014 Tentang Forum Koordinasi Pengelolaan Warisan Dunia Lansekap Budaya Provinsi Bali.

\section{Putusan Pengadilan}

Putusan Mahkamah Konstitusi Republik Indonesia Nomor 31/PUU-V/2007 tentang Pengujian Undang-Undang Nomor 31 Tahun 2007 tentang Pembentukan Kota Tual di Propinsi Maluku. 